\title{
Jezik i igra - prikaz jedne osobene knjige
}

\section{Antonić, Ivana (ur.), Svenka Savić: Između baletske i jezičke igre. Novi Sad: Ženske studije i istraživanja: Futura publikacije, 2020, str. 320.}

Ivana Antonić je uredila jedinstven monografski zbornik pod nazivom Svenka Savić: Između baletske i jezičke igre povodom 60 godina rada i 80 godina života profesorke emerite Filozofskog fakulteta Univerziteta u Novom Sadu. Sam naslov knjige odmah upućuje na cilj kojem je Svenka Savić oduvek stremila - interdisciplinarnost.

Urednica je okupila tim saradnica i saradnika Svenke Savić da objedini njihova znanja i iskustva u području interdisciplinarnog rada i saradnje sa njom. Ukupno, knjiga objedinjuje sedam priloga, od kojih šest obrađuju tri tematske oblasti koje su obeležile profesionalni rad S. Savić: lingvistiku, umetničku igru i ženski (i drugi) aktivizam, a sedmi prilog predstavlja bogatu bibliografiju njenih radova iz tih oblasti u domenu nauke i umetnosti. U prva tri priloga doznajemo o radu S. Savić u domenu teorijske lingvistike, psiholingvistike, analize diskursa, feminističke lingvistike i feminističke teologije (u knjizi izostaje njena bogata delatnost u domenu jedne druge naučne interdiscipline - romologije - koju detaljno obrađuje u knjizi Kako je muški rod od devica?).

Ivana Antonić u tekstu Psiholinvistika Svenke Savić piše o istraživačkom i akademskom radu profesorke, sa kojom je sarađivala tokom studija i početkom profesionalne karijere (1982-1991) na dugoročno osmišljenom projektu Psiholingvistička istraživanja. Autorka predstavlja analizu prve dve faze naučnoistraživačkog rada S. Savić, odnosno tri etape njenog bavljenja naukom o jeziku: 1) monodisciplinarnu (lingvistika), 2) interdisciplinarnu (psiholingvistika - razvojna i primenjena - i analiza diskursa) i 3) multidisciplinarnu (kritička analiza diskursa - feministička lingvistika, feministička teologija, romologija). Prva faza je trajala kratko (tokom druge polovine 60 -ih godina XX v.), a obeležila su je istraživanja u oblasti 
sintakse i sintaksičke stilistike na, kako autorka ističe, zavidnom korpusu pisanog srpskohrvatskog jezika, dobivši konačnu realizaciju u vidu dva obimna rada. Ivana Antonić smatra da su ova istraživanja i danas značajna i aktuelna za sintaksu, iako je Svenka Savić napustila monolingvistička istraživanja (ocenjujući ih kao tradicionalno lingvistički pristup) i usmerila se na interdisciplinarne pristupe.

Ivana Antonić ocenjuje da je druga faza profesionalnog usmerenja Svenke Savić trajala tri decenije. Obeležila ju je interdisciplinarna orijentacija s dve etape, psiholingvističkom (1971-1990) i analizom diskursa (1985-2000), koje povezuje pragmatika i povremeno sagledavanje jezičkih pojava sa sociolingvističkog, kulturološkog i kognitivnog aspekta. Autorka smatra da je psiholingvistika polje u kojem je S. Savić dala najviše naučnog doprinosa: u oblastima usvajanja jezika, njegovog razvoja i upotrebe u komunikaciji, i za koju njeno interesovanje ne jenjava ni danas. Zato zaključuje da je akademska karijera S. Savić dominantno usmerena na polje interdisciplinarnosti u kom dolazi do izražaja njena dinamična ličnost, želja za povezivanjem i sklonost ka timskom radu. Pomerajući svoj fokus sa formalističkog ili strukturalističkog izučavanja langue, stilski doteranog, pisanog, uređenog jezika visokog stila, na parole, svakodnevni, neuređen jezik, jezik na koji nailazimo „na ulici” (na kojem psujemo), S. Savić pristupa prikupljanju empirijskog materijala i izučavanju ,živog” jezika, koji nije lako izučavati upravo zbog (prividnog) ,nereda” i ,zbrkanosti” koje u njemu nalazimo. Njena zanimljiva i agilna ličnost je, čini se, oduvek bila u saglasju s ovakvim naučnim pogledom na jezik, koji je, kao i ona sama, ekspresivan, raznolik i sve samo ne linearan. Svoj dar da zainteresuje, pokrene, poveže i organizuje mlade studente lingvistike, ali i one dovoljno istraživački radoznale i ne obavezno naučno opredeljene, koristila je nesebično u nastojanju da raširi svest o tome da nauka o jeziku ne treba biti izolovana od drugih nauka nego da u povezivanju s drugim može dati najviše, posebno korisnicima jezika. Za sada je ova analiza doprinosa Svenke Savić razvoju akademske discipline psiholingvistike kod nas jedina i otuda može biti model za analizu profesionalnog doprinosa i drugih profesora u nauci o jeziku kod nas.

Margareta Bašaragin sarađuje sa Svenkom Savić od doktorskih studija (2012) do danas. U tekstu Feministička lingvistika prikazuje osnovni 
put interdisciplinarnog istraživanja jezika i roda kojim se S. Savić bavi u dugom vremenskom periodu (1968-2020), opisujući tok bavljenja ovom oblašću, od početaka njenog interesovanja za pitanja feminističke lingvistike uz pomeranje fokusa sa strukturalističkog pristupa na odnos jezika i mišljenja i njegovu upotrebu u realnom kontekstu. Autorka povezuje ovaj interdisciplinarni pravac sa postepenim feminističkim aktivizmom, a naročito zalaganjem za pitanja standardizacije rodno osetljivog jezika u službenoj i javnoj upotrebi u Srbiji. Obuhvatila je teorijski i istraživački rad Savić na jezičkom materijalu koji je izopšten od glavnih lingvističkih tokova kod nas (razgovorni jezik, upotreba jezika grupa sa manje društvene moći - dece, migranata, žena i dr.) koji je vodio do akademskog aktivizma (najviše u osnivanju i vođenju rodnih studija), a od posebnog značaja je za S. Savić i saradnja sa ženskim i nevladinim organizacijama u zemlji i regionu. Ono što je novo u ovom poglavlju jeste kombinacija razgovora (intervjua) autorke sa svojom profesorkom i ocene njenog doprinosa, čime se istovremeno i smanjuje distanca između profesorke i saradnice. Tu su utkana dva glasa - glas profesorke i glas ocenjivačice - što nije uobičajen način predstavljanja podataka (u ovom slučaju onih koji njih dve povezuju). Prilog pokazuje da je posebna zasluga Svenke Savić u negovanju nastavnog kadra koji sada broji već tri generacije nastavnica i nastavnika koji istražuju u različitim domenima nauke o jeziku.

Zilka Spahić Šiljak iz Sarajeva sarađuje sa Svenkom Savić od 2002. godine (kada je prijavila i odbranila doktorski rad na ACIMSI Centru za rodne studije UNS i nastavila akademsku karijeru na interdisciplinarnim Religijskim i Rodnim studijama u Sarajevu). Tom profesionalnom prijateljstvu je posvećen tekst pod nazivom Na krilima feminizma i ekumenizma. U njemu autorka, u formi intervjua, ličnih refleksija i analize objavljenih knjiga i tekstova S. Savić iz domena teologije i jezika sumira rezultate rada, s ciljem da ukaže na njen doprinos ustanovljavanju i razvoju nove naučne discipline kod nas - feminističke teologije. Istovremeno, u okviru te discipline ona afirmiše pristup iz perspektive ekumenizma i međureligijskog dijaloga kada uvodi i rodnu perspektivu (kod nas). Tekst je podeljen u tri dela. Prvi deo opisuje angažman S. Savić u oblasti feminističke teologije kroz analizu diskursa svetih tekstova i analizu govorenih propovedi sveštenika za vreme službe u crkvi, prikazujući je kao 
naučnicu čija intelektualna radoznalost teži interdisciplinarnosti i multidisciplinarnosti, i koja se ne ograničava društvenopolitičkim i kulturološkim normama, te izlazi izvan poznatog i društveno prihvatljivog. U drugom delu autorka obrađuje njen akademski i vernički angažman u oblasti ekumenizma i međureligijskog dijaloga iz rodne perspektive, prenoseći svoje refleksije na feminističku etiku brige. Ovde je fokus na religijskom diskursu (način na koji sveštenici propovedaju, kako se obraćaju vernicima i sl.) i važnosti feminističke teologije kao oblika kritičke analize i dekonstrukcije postojećeg. Čitaoce i čitateljke posebno mogu zainteresovati intervjui o interesovanju Svenke Savić za religiju, o razumevanju feminizma i feminističke lingvistike, razgovor o tekstu o Isusu i Samarjanki i njegova analiza uz pomoć analize diskursa, ali i o tome kako povećati vidljivost žena u naučnim tekstovima. Treći deo govori o interesovanju S. Savić za analizu sadržaja udžbenika veronauke, posebno za položaj žene u hrišćanskim konfesijama i za prisutnost ekumenskog i međureligijskog dijaloga u tim udžbenicima. Ukazuje, očekivano, na implicitnu i eksplicitnu diskriminaciju žene u tim udžbenicima. Posebno zanimljivu ilustraciju važnosti kulturoloških, jezičkih i drugih međureligijskih sličnosti i razlika za razumevanje među ljudima autorka daje kroz svoju analizu molitvi, El-Fatihe iz Kur'ana i Očenaša iz Biblije. Na osnovu sprovedene analize, autorka sažima njen celokupan akademski i aktivistički rad na dve reči: povezivanje i razumevanje.

Za razliku od višedecenijske tradicije u evropskim zemljama, Feministička teologija se ne predaje ni na jednom od postojećih fakulteta u Srbiji (sem kao izborni kurs na ACIMSI Centru za rodne studije UNS, koji je S. Savić predavala dok je ovaj Centar postojao). To je podatak koji posebno naglašava individualnu profesionalnu aktivnost ove istraživačice, ali i Zilke Spahić Šiljak, kao pionirsku kod nas danas.

Vera Obradović Ljubinković je najpre prijavila (2009), a onda odbranila doktorski rad pod mentorskim rukovođenjem Svenke Savić u Centru za rodne studije ACIMSI UNS iz domena umetničke igre. Od tada pa do danas uspešno sarađuju na mnogim projektima, što je u osnovi njenog poglavlja naslovljenog Svenka Savić: Hajde da počnemo dijalog i/ili Kako se ostvaruju dodiri nespojivog. Autorka analizira doprinos S. Savić umetničkoj igri kroz njene tekstove, kritičku i polemičku reč, i moguće dijaloge i veze koje ostvaruje među različitim disciplinama, unoseći znanje 
i iskustvo iz nauke o jeziku u pisanje o klasičnom baletu i promišljajući igru pomoću jezika, s primarnom rodnom perspektivom. Rad je obogaćen ličnim i profesionalnim sagledavanjem S. Savić uz navođenje hronologije njihovih susreta iz pozicije odnosa mentorka-doktorantkinja, i utisaka, kao i delova prepiske vođene tokom više godina, uz dopunjavanje delovima razgovora koji su vodile za priliku pisanja ovog priloga. Ovakav metod pisanja je nov, i reklo bi se, neponovljiv, u kojem podjednako pulsiraju emocije koliko i stroga naučna analiza, ali najviše prijateljstvo dveju žena. One su se susrele u semiotici igre u klasičnom baletu sa semiotikom jezika u svakodnevici. Autorka tekst dokumentuje pouzdanim brojnim radovima S. Savić i po tome je ovo poglavlje od posebne koristi svima koji se na bilo koji način bave igrom i jezikom kod nas. Cilj koji autorka postavlja jeste da što preciznije sagleda i oslika umetnicu, kritičarku umetnosti igre i naučnicu kroz interdisciplinarnost i interkulturalnost, koja se ogleda u dvojstvu umetnosti i nauke, i koju ona primenjuje povezujući semiotiku igre u klasičnom baletu sa semiotikom jezika.

Radove o igri S. Savić je objavljivala u knjigama i časopisima koje srbisti i lingvisti uglavnom ne konsultuju. Tako je sada dragocena lista njenih objavljenih tekstova o baletskoj terminologiji, zatim o bliskosti semiotike igre i semiotike jezika. Tu vrstu naučne preciznosti iz nauke o jeziku ona je primenila u opisivanju doprinosa dvaju značajnih koreografa koji su delovali u Baletu Srpskog narodnog pozorišta - Iko Otrin i Lidija Pilipenko, sa kojima je usko sarađivala. Nažalost, u bogatom inventaru onoga što je S. Savić o baletu pisala te dve analize ostale su manje vidljive u autorskom tekstu V. Obradović Ljubinković.

Miloš Pankov je bio student na Odseku za srpski jezik i lingvistiku kome je Svenka Savić najpre predavala Analizu diskursa (1995), potom je odbranio diplomski rad, sarađivao sa njom na izradi magistarskog rada i, konačno, odbranio doktorsku disertaciju pod njenim mentorstvom. Autor prenosi sećanja profesorke Snežane Marinković, nekadašnje studentkinje profesorke Savić, koja na upečatljiv i (na osnovu ličnog sećanja autorke ovog prikaza) veran način opisuje profesorku Savić:

U učionicu je ušla srdačno, neposredno i zadihano [...] Ulepršala je kao balerina, što ona stvarno i jeste bila. Pozdravila nas je šarmantnim zvonkim smehom. Gledala nas je sve ravno u oči kada se predstavila [...] Govorila je brzo, pametno i provokativno [...] Bila je drugačija od svih onih koje smo imali prilike da sretnemo pre i posle nje. 
Razlikovala se po sadržajima koje je prezentovala na svojim predavanjima, nisu bili čisto akademski, ispošćeni, već su bili životni ${ }^{1}$.

U dugoj zajedničkoj saradnji Pankova i S. Savić stvorilo se poverenje da upravo on napiše poglavlje naslovljeno Svenka Savić u medijima, koje predstavlja njenu ukupnu medijsku prisutnost (1963-2020) tokom profesionalne karijere. Dragoceni su kvantitativni prikazi različitih prezentacija u različitim medijima: pisanim, govorenim na radiju i na televiziji, ili u video-zapisima i filmovima. Svoje istraživanje autor sprovodi metodom analize diskursa u kombinaciji sa metodom životne priče, na korpusu tekstova u štampanim medijima (polemike, članci, kolumne, prikazi knjiga i tekstovi koji su pisani o njoj - ukupno 146), radijskih emisija (445), televizijskih programa (32) i filmova (15). Prilog potvrđuje da je Svenka Savić jedna od retkih naučnica koja piše za medije, što potvrđuje čak 638 priloga. Njen medijski angažman, s jedne strane, usmeren je na afirmaciju metoda interdisciplinarnog pristupa nauci o jeziku, a s druge, na povremeno naglašeno zalaganje za neki od aspekata takvog pristupa, pri čemu je najduže posvećena afirmaciji rodno osetljivog jezika.

Autor potencira da je medijski angažman za Svenku Savić oduvek bio deo profesionalnog identiteta, budući da ona smatra da profesori i profesorke imaju uticaj na svoje studente i studentkinje ne samo svojim nastavnim radom nego i vannastavnim aktivnostima i ponašanjem. Kao potvrda bogate medijske prisutnosti u dodatku radu autor prilaže ličnu i profesionalnu biografiju hronološkim redosledom događaja (str. 199-206), zatim su tu i podaci o članstvu u strukovnim udruženjima i organizacioni rad (str. 207-208), koji sami po sebi mogu biti osnova budućoj analizi povezanosti ličnih i profesionalnih događaja žene koja je dosegnula zvanje profesorke emeritus (za sada jedina iz domena nauke o jeziku sa Filozofskog fakulteta UNS). U ovom postupku Pankov sledi pristup koji je Vera Vasić primenila deset godina ranije, povodom uređivanja Zbornika u čast Svenki Savić (2010), u kojem piše:

Priređujući zbornik u čast Svenki Savić, prvoj profesorki emeriti Filozofskog fakulteta Univerziteta u Novom Sadu, rukovodila sam se time da su njena nastavna i naučna

${ }^{1}$ M. Pankov (2020). Svenka Savić u medijima. U: Svenka Savić: između baletske i jezičke igre. Ur. I. Antonić. Novi Sad: Ženske studije i istraživanja - Futura publikacije, str. 159. 
delatnost bile u čvrstoj vezi, bez obzira na to da li su je predavanja vodila ka naučnim i stručnim radovima ili su oni, uz pročitano, bili izvor tema za predavanja, mentorski rad na dodiplomskim i postdiplomskim studijama, za razgovore sa saradnicama i saradnicima, među kojima sam dugi niz godina bila i ja².

Ono što ostaje za buduću analizu tekstova Svenke Savić u medijima jesu njene polemike ili diskusije koje je vodila, najviše o važnosti standardizacije rodno osetljivog jezika, ali i standardizacije romskog jezika (tema koja, nažalost, u ovom zborniku izostaje). Svenka Savić je zapravo jedina profesorka koja polemiše o jezičkim pitanjima važnim za standardizaciju: upotreba dvaju pisama u našem jeziku (ćirilice i latinice), i o različitim oblicima diskriminacije različitih grupa građana (mladih, starih, žena i sl.) pomoću jezika. U srbistici inače nema mnogo polemika (nekoliko ih je samo poznatijih među muškarcima, kao što su one u kojima je učestovao Pavle Ivić, ili one koje je više godina vodio Dragoljub Petrović, profesori istog Odseka za srpski jezik i lingvistiku na kojem je i S. Savić). Polemike u kojima profesorka Savić učestvuje odnose se na različite upotrebe u jeziku, kojima ona želi da afirmiše teorijski pristup kojem pripada - teorije jezičke delatnosti.

Prilogom Bibliografija radova dr Svenke Savić, profesorke emerite (1963-2020) na 95 stranica (213-308) Nataša Belić završava profesionalni portret profesorke, s kojom prijateljstvo i saradnja traju gotovo tri decenije (od 1994, kada je N. Belić bila najpre studentkinja, potom saradnica, i u poslednje dve decenije bibliografkinja radova S. Savić, koji su objedinjeni u ovoj knjizi). Podaci u ovom prilogu poslužili su ostalim saradnicama i saradnicima kao početni materijal. Ali, kako piše i Nataša Belić, ne znači da je ovim spiskom Svenka Savić stavila tačku na produkciju tekstova i aktivnosti. Autorka je ukupnu bibliografsku građu od 805 bibliografskih jedinica (i oko trideset uloga u baletskim predstavama tokom 8 godina njenog aktivnog članstva u ansamblu Baleta SNP) rasporedila hronološkim sledom u 11 celina: 1) posebna izdanja; 2) prilozi u serijskim publikacijama, monografijama i zbornicima radova; 3) intervjui; 4) prevodi; 5) recepcija dela Svenke Savić; 6) video-zapisi; 7) radio-zapisi; 8) odrednice u enciklopedijama i leksikonima; 9) doktorske disertacije

${ }^{2}$ V. Vasić (2010). Urednička beleška. U: Diskurs i diskursi. Zbornik u čast Svenki Savić. Ur. V. Vasić. Novi Sad: Filozofski fakultet, str. 11. 
(mentorski rad); 10) prilozi na portalima; 11) uloge Svenke Savić u predstavama Srpskog narodnog pozorišta u Novom Sadu.

Na kraju knjige su: sažetak na engleskom jeziku (u prevodu Vesne Gerić, dugogodišnje saradnice i prijateljice Svenke Savić, čiju je životnu priču S. Savić objavila u knjizi Profesorke Univerziteta u Novom Sadu, 2012, 404-418), a zatim slede i osnovni biografski podaci (uz fotografije) saradničkog tima u knjizi. Pomenućemo na kraju i ne manje važne doprinose recenzenata Zbornika prof. dr Vesnu Krčmar i dr Uglješu Belića.

Knjiga Svenka Savić: Između baletske i jezičke igre može biti iskorišćena i u inventaru knjiga o ženskom prijateljstvu u nauci. Saradnice i saradnici su pokazali koliko je profesorka uticala na njih, ali je sigurno da je i ona upijala njihove uticaje.

Ovako bogat i plodan, dug profesionalni put Svenke Savić nije moguće u potpunosti opisati u jednoj knjizi niti ga sažeti u tolikoj meri da se ne izostavi još važnih i zanimljivih podataka iz njenog života i profesionalne karijere. Otuda ni ovaj prikaz ne može obuhvatiti sve. Ipak, podaci ovako objedinjeni na jednom mestu dokazuju početak razmatranja doprinosa pojedinaca i pojedinki razvoju srbistike, u ovom slučaju u međuzavisnosti sa nekom drugom naučnom disciplinom u onome što je do sada poznato kao novosadska škola (lingvistike). Ono što ostaje da se istraži jesu putevi kojima su se razilazile generacije studentkinja sa kojima je profesorka Savić sarađivala na projektima, na izradi doktorskih i drugih radova. Možemo očekivati od nje same da nam „dopiše” i tu istoriju smene generacija.

Zaključujem da je urednica Ivana Antonić imala težak zadatak da objedini različite aspekte profesionalne aktivnosti Svenke Savić u dugom vremenskom periodu od 60 godina, s vođenjem računa da u njemu pulsira njena, po svemu osobena ličnost. Urednica je obezbedila saradničkom timu prostor da se mogu dobro osećati u svom pristupu, pa je ovaj monografski zbornik istovremeno saradničko delo ,profesorki u čast”, objedinjeno željom da lična sećanja i jedinstven profesionalni put Svenke Savić budu primer povezivanja (nespojivog) nauke i umetnosti. Možda pristup koji pomera granice. 